\title{
Restitusjon og gjenoppretting i norsk urfolksrett
}

Av professor dr. juris $\varnothing$ yvind Ravna

Mange urfolk har over tid blitt fratatt betydelige deler av sine tradisjonelle landområder som følge av kolonisering, tvungen landavståelse, industrialisering og annen samfunnsutvikling. Retten til restitusjon eller gjenoppretting er i rettslig sammenheng det internasjonale rettssamfunnets regel for å reparere den urett folkegrupper er blitt utsatt for ved urettmessige beslag av landområder. I denne artikkelen drøftes rekkevidden av denne regelen $\mathrm{i}$ internasjonal rett, før det undersøkes i hvilken grad det er dekning for en slik regel i norsk rett.

Nøkkelord: gjenoppretting, ILO-konvensjon nr. 169, restitusjon, samerett, urfolksrett

Øyvind Ravna (f. 1961) er professor i rettsvitenskap ved Det juridiske fakultet, UiT Norges arktiske universitet, og professor II ved Samisk Høyskole, Kautokeino. Hans sentrale arbeidsfelt er tingsrett og same- og urfolksrett. Han har bl.a. skrevet bøkene Rettsutgreiing og bruksordning i reindriftsområder (2008), Finnmarksloven - og retten til jorden i Finnmark (2013) og Same- og reindriftsrett (2019).

\section{Innledning ${ }^{1}$}

Som følge av «klassisk» kolonisering og tvungne landavståelser, men også nyere tiders samfunns- og industrielle utvikling, har en rekke urfolk blitt fratatt herredømmet over betydelige deler av sine landområder. Det innebærer at de områder som urfolkssamfunn i dag besitter og bruker, bare utgjør deler av det området disse samfunnene en gang brukte og rådet over.

Også samene i Norge har blitt utsatt for kolonisering, inngrep og fratakelse av råderett over landområder de tradisjonelt har besittet og brukt. Dette har dog ikke skjedd ved hjelp av militærmakt, svikefulle avtaler eller fordrivelse, slik tilfellet eksempelvis har vært for urfolkene i Nord- og SørAmerika. I Sápmi har dette i hovedsak skjedd ved [567]jordbruks- og senere industriekspansjon, støttet av lovvedtak og rettsprosesser som knapt kan sies å ha vært rettmessige i sin samtid. Det kan også hevdes at en fornorskningspolitikk, støttet av en gradvis fordreining av rettshistorien, har bidratt til det samme.

\footnotetext{
${ }^{1}$ Artikkelen er basert på foredraget «Restitusjon og gjenoppretting», holdt på seminaret ILO-konvensjon 169 fyller 30 år $i$ Norge, arrangert av Forskergruppe for same- og urfolksrett ved UiT Norges arktiske universitet på Troms $\emptyset$ bibliotek, 20. juni 2020.
} 
Realiteten er videre at mens $\emptyset$ konomisk vederlag i form av ekspropriasjonserstatning i de fleste tilfeller vil være dekkende kompensasjon for enkeltindivider som utsettes for eiendomsinngrep, ${ }^{2}$ vil det ikke være det for en folkegruppe som har lang og tradisjonell tilknytning til sitt land. Federico Lenzerini påpeker at $\emptyset$ konomisk erstatning er utilstrekkelig der urfolk har mistet landområder, da «moderlandet» for de fleste urfolkssamfunn representerer en åndelig betydning intet pengebeløp kan utlikne. ${ }^{3}$ Lenzerini viser bl.a. til at urfolksrepresentanter i en FN-arbeidsgruppe opprettet i forbindelse med et resolusjonsarbeid i FNs menneskerettighetskommisjon, ${ }^{4}$ uttalte at $\varnothing$ konomisk kompensasjon ikke gir tilstrekkelig oppreisning for påført tap:

«Forestillingen om 'rett og rettferdig' kompensasjon for urfolk innebærer ikke bare kompensasjon basert på 'riktig markedsverdi', da urfolks landområder, territorier og ressurser helt enkelt ikke kun er fast eiendom. Tvert imot, det dyptgående forholdet urfolk har til sine landområder og territorier, har kritiske sosiale, $\varnothing$ konomiske, politiske, kulturelle og åndelige dimensjoner.. ${ }^{5}$

Kravet om tilbakeføring av Black Hills i lakotafolkets tradisjonelle landområder i Sør-Dakota, USA er i så måte et betegnende eksempel: De forente stater beslagla med militærmakt i 1877 Black Hills fra lakotaene etter at det ble funnet gull i det urfolket regnet som sitt arnested og hellige fjellområde. Etter nærmere 100 års kamp i rettssystemet kom De forente staters høyesterett til at beslaget var ulovlig, og besluttet [568]at det skulle erstattes med et pengebeløp. ${ }^{6}$ Lakotaene ville imidlertid ha tilbake sitt fjellområde og nektet å ta imot beløpet, som ennå står på en konto forvaltet av Bureau of Indian Affairs. ${ }^{7}$

Retten til restitusjon eller gjenoppretting er i denne sammenheng det internasjonale rettssamfunnets regel for å reparere den urett folkegrupper er blitt utsatt for ved urettmessige beslag av landområder.

${ }^{2}$ Dette er den alminnelige måten mange rettsstater gjør opp for fratakelse av land til fordel for samfunnets behov. I norsk rett kan det bl.a. vises til lov 23. oktober $1959 \mathrm{nr} .3 \mathrm{om}$ oreigning av fast eigedom, forankret i eiendomsvernet i Grunnloven § 105.

${ }^{3}$ Federico Lenzerini, «Reparation, Restitution, and Redress. Articles 8(2), 11(2), 20(2), and 28», Hohmann og Weller (red.), The UN Declaration on the Rights of Indigenous Peoples, A Commentary, Oxford University Press, Oxford 2018, s. 573-598, på s. 574.

${ }^{4}$ FNs menneskerettighetskommisjon var et FN-organ som arbeidet med menneskerettigheter i nært samarbeid med FNs høykommissær for menneskerettigheter. FNs Generalforsamling vedtok i 2006 å erstatte organet med FNs menneskerettighetsråd, se Store norske leksikon, https://snl.no/FNs_menneskerettighetsråd (19. aug. 2020).

${ }^{5}$ Lenzerini, «Reparation, Restitution, and Redress. Articles 8(2), 11(2), 20(2), and 28», s. 574 med henvisning til Report of the Working Group Established in Accordance with Commission on Human Rights Res 1995/32, UN Doc E/CN.4/2002/98 (6 March 2002) para 81 (min oversetting her og andre steder der annet ikke er nevnt).

${ }^{6}$ United States v. Sioux Nation of Indians, 448 U.S. 371 (1980), avgjort 30. juni 1980, ChanRobles Virtual Law Library. Se også Edward Lazarus, Black Hills / White Justice, HarperCollins, New York 1991.

${ }^{7}$ Øyvind Ravna, Fra Little Bighorn til Standing Rock. En moderne indianerhistorie, Orkana 2018, s. 243. 
Problemstillingen for dette arbeidet er todelt. Det vil først bli unders $\varnothing \mathrm{kt}$ hva internasjonal rett sier om rekkevidden av restitusjonsregelen, med andre ord hvordan stater og deres lovanvendere må forholde seg rettslig til historiske disposisjoner som har medført at urfolk på permanent grunnlag har mistet sin eiendomsrett til områder de tradisjonelt har rådet over. Dernest vil det bli undersøkt i hvilken grad en slik rettsregel er forankret i norsk rett. Temaet omfatter således spørsmålet om i hvilken grad urfolksretten har utviklet og frambrakt en erkjennelse av at urfolk har eiendoms- og besittelsesrettigheter også til områder som de i nyere tid er fratatt råderetten over uten deres samtykke.

Temaet aktualiseres av den pågående rettskartleggingen i Finnmark, hvor Finnmarkskommisjonen i sin inntil nå siste utredning, framlagt i desember $2019,{ }^{8}$ anvender restitusjonsregelen. Den er i praksis ikke prøvd av norske domstoler.

Rettskildemessig vil arbeidet i all hovedsak basere seg på sekundærkilder for å undersøke rettsstatus internasjonalt, mens studien av norsk rett vil være basert på autoritative primærkilder og empirisk materiale.

\section{Rettsgrunnlag i internasjonal rett}

\subsection{ILO-konvensjon nr. 169}

ILO-konvensjon nr. 169 om urfolk og stammefolk i selvstendige stater (ILO 169) ${ }^{9}$ er den eneste internasjonale konvensjonen hvor urfolk alene er rettssubjekt, og som sådan beskytter urfolks kultur og rett til eiendom. Selv om konvensjonens del III (artikkel 13 til 19) omhandler landrettigheter, innehar den ingen bestemmelse som eksplisitt omhandler restitusjon og gjenoppretting. Artikkel 14 (1) første punktum sier kun at urfolk har krav på eiendoms- og bruksrett til landområder de på tradisjonelt grunnlag besitter. Artikkel 14 lyder i norsk oversettelse ${ }^{10}$ slik: [570]

«1. Vedkommende folks eiendoms- og råderett til de landområder som de tradisjonelt besitter, skal anerkjennes. Når forholdene tilsier det, skal det også treffes tiltak for å sikre vedkommende folks rett til å bruke landområder som de ikke besitter alene, men som de tradisjonelt har hatt tilgang til for sitt

\footnotetext{
${ }^{8}$ Finnmarkskommisjonen, Rapport felt 4 Karasjok, bind 1.

${ }^{9}$ ILO Convention No. 169, Indigenous and Tribal Peoples Convention, vedtatt på 76th ILC session 27, juni 1989, ratifisert av Norge 20. juni 1990, i kraft 5. september 1991.

${ }^{10}$ Regjeringen.no, ILO-konvensjon nr. 169 om urfolk og stammefolk i selvstendige stater, se https://www.regjeringen.no/no/tema/urfolk-ogminoriteter/samepolitikk/midtspalte/ilokonvensjon-nr-169-om-urbefolkninger-o/id451312/ (20. 07.2020).
} 
livsopphold og sin tradisjonelle virksomhet. I denne sammenheng skal det legges spesiell vekt på situasjonen for nomadiske folk og personer som driver flyttejordbruk.

2. Regjeringene skal etter behov ta nødvendige skritt for å kartlegge de landområder som vedkommende folk tradisjonelt besitter, og sikre effektivt vern av deres eiendoms- og råderett.

3. Hensiktsmessige ordninger skal sikres i den nasjonale rettsorden for å avgjøre rettskrav knyttet til landområder fra vedkommende folk.»

Det er i praksis lagt til grunn at artikkel 14 må forstås slik at urfolks rett til å eie sine tradisjonelle landområder ikke kun omfatter områder de per i dag besitter, men også områder som de er blitt fratatt i nyere tid. I en klagesak fremmet mot Danmark i år 2000, som følge av at folket i Uummannaqbosettingen i Thule-distriktet på Grønland i 1953 var blitt forflyttet mot sin vilje (på grunn av etablering av en amerikansk militærbase), ${ }^{11}$ satte de tvangsflyttede inuittene fram krav om erstatning for forflytningen, samt om eiendomsrett til sitt tidligere bosetningsområde. ILOs trepartskomité fant at erstatningskravet var rettmessig, men derimot ikke at eiendomskravet var det. ${ }^{12}$ Saken viser imidlertid at krav om eiendomsrett er relevant å vurdere selv om det har gått nærmere 50 år. ILOs trepartskomité påpekte her at ILO 169 (som trådte i kraft for Danmark 22. februar 1997) ikke kunne gis tilbakevirkende kraft. Kravet kunne likevel vurderes ut fra sin virkning:

«Komiteen bemerker [...] at virkningene av flyttingen fra 1953 vedvarer i dag, ved at de omplasserte personene ikke kan vende tilbake til Uummannaq-bosetningen, og at juridiske krav til dette landområdet fortsatt ikke er avgjort. Følgelig mener komiteen at konsekvensene av flyttingen som vedvarer etter ikrafttredelsen av konvensjon nr. 169, fortsatt trenger å bli vurdert med hensyn til artikkel 14 (2) og (3), 16 (3) og (4) og 17 i konvensjonen [...], til tross for at flyttingen fant sted før konvensjonen trådte i kraft.» ${ }^{13}$

\footnotetext{
${ }^{11}$ Helge Schultz-Lorentzen, Karsten Sommer og Rasmus Ole Rasmussen, «Qaanaaq», Den store danske, lex.dk (22.07.20).

${ }^{12}$ Representation (Article 24), 2000, Denmark, C169, Report of the Committee Set up to Examine the Representation Alleging Non-Observance by Denmark for the Indigenous and Tribal Peoples Convention, 1989 (No 169), Made under article 2. of the ILO Constitution by the National Confederation of Trade Unions of Greenland (Sulinermik Inuussutissarsiuteqartut Kattuffiat-SIK) (SIK), https://www.elaw.org/content/denmark-report-committee-set-examine-representationalleging-non-observance-denmark-ilo-169- (20.07.2020).

${ }^{13}$ Ibid. avsnitt 29.
} 
Trepartskomiteen behandlet således eiendomskravet, men fant at det ikke kunne føre frem da den grønlandske selvstyreloven av 1977 § 8 (1) slo fast at grønlenderne hadde en fundamental, kollektiv rett til dette området. ${ }^{14}$

Ser vi på ILO-guiden fra 1996, er det også lagt til grunn at konvensjonens bestemmelser om landrettigheter innebærer en rett til gjenoppretting, om enn en begrenset sådan. Ifølge denne ILO-guiden må dagens urfolkssamfunn ha opprettholdt en form for tilknytning til det aktuelle landområdet for at retten til restitusjon skal gjelde. Som et eksempel nevner ILO-guiden situasjonen som foreligger når en urfolksgruppe relativt nylig er blitt bortvist eller fordrevet fra sitt tradisjonelle landområde. ${ }^{15}$ Dette bekreftes i ILO-guiden fra 2009, hvor det med henvisning til ILOs kontrollorganer uttales at urfolks rett til land i noen tilfeller kan omfatte områder som nylig har gått tapt, eksempelvis som følge av forflytninger fra land de tidligere har bebodd. ${ }^{16}$

Mattias Åhren påpeker at det er usikkerhet om i hvilken grad nasjonalstatene, og dermed det internasjonale samfunnet, har akseptert ILO-sekretariatets tolkning av ILO $169,{ }^{17}$ som i seg selv ikke kan sies å være veldig langtrekkende.[571]

Åhren går imidlertid inn på annen FN-praksis og viser at de tre FN-organene som har størst betydning i urfolkssammenheng, nemlig FNs komité for økonomiske, sosiale og kulturelle rettigheter, FNs menneskerettighetskomité og FNs komité mot rasediskriminering, alle har drøftet retten til restitusjon med relevante uttalelser. Det behandles i det følgende.

\subsection{FNs konvensjon mot rasediskriminering, FNs komité for økonomiske, sosiale og kulturelle rettigheter og FNs menneskerettighetskomité}

FNs komité mot rasediskriminering (ICERD) har utledet en rett til restitusjon av FNs konvensjon mot rasediskriminering. Komiteen oppfordrer stater der urfolk er blitt fratatt sine landområder og territorier

${ }^{14}$ Ibid. avsnitt 37. Se også NOU 2007: 13 Den nye sameretten s. 435.

${ }^{15}$ Mattias Åhren, Indigenous Peoples' Status in the International Legal System, Oxford University Press, Oxford 2016, s. 195-196 med henvisning til Manuela Tomei og Lee Swepston, Indigenous and Tribal Peoples: A Guide to ILO 169.

${ }^{16}$ Indigenous \& Tribal Peoples' Rights in Practice. A guide to ILO Convention No. 169 (2009), s. 94 med videre henvisning til ILO Governing Body, 276th Session, November 1999, Representation under article 24 of the ILO Constitution, Mexico, GB.276/16/3, para. 37.

${ }^{17}$ Åhren, Indigenous Peoples' Status in the International Legal System, s. 195, hvor det pekes på at ILO 169 Artikkel 16 (3) ved første øyekast kan se ut til å gi en rett til restitusjon, da bestemmelsen forkynner at urfolk som hovedregel har rett til å få land tatt uten samtykke, tilbake. Ved nærmere gjennomgang er det imidlertid klart at anvendelsen av artikkel 16 (3)-(4) er begrenset til situasjoner der urfolk er blitt tvangsflyttet fra sine tradisjonelle territorier i henhold til artikkel 16 (2), som er et unntak fra det generelle forbudet mot tvangsflytting i artikkel 16 (1), skriver Åhren: Med andre ord gjelder retten til restitusjon etter artikkel 16 (3)-(4) bare for landområder som er beslaglagt i samsvar med unntaket artikkel 16 (2), etter at en statspart har ratifisert ILO 169. 
som de tradisjonelt har eid eller på annen måte bebodd eller brukt, uten deres frie og informerte samtykke, til å ta skritt for å returnere disse landområdene. ${ }^{18}$ Når restitusjon og gjenoppretting i form av tilbakeføring av beslaglagt land ikke er mulig, bør gjenoppretting ifølge ICERD skje i form av tildeling av alternative landområder. Komiteen anfører følgelig at retten til eiendom, vurdert opp mot retten til ikke å bli diskriminert, innebærer at nasjonalstatene ikke bare plikter å anerkjenne urfolks eiendomsrett til tradisjonelle områder de i dag bruker, men også til land som er fratatt dem uten samtykke i tidligere tider.

Åhren viser til at rasediskrimineringskomiteen senere har utdypet denne generelle observasjonen ved å uttrykke bekymring for at fraværet av et effektivt system for restitusjon av landrettigheter forhindrer urfolkssamfunn i å få tilgang til sine forfedres landområder. Han viser også til at komiteen har bedt en statlig part (Paraguay) om å vedta nødvendige reformer for å bidra til restitusjon av urfolkssamfunns landområder. ${ }^{19}$

Åhren peker også på at FNs komité for økonomiske, sosiale og kulturelle rettigheter (CESCR) har gjentatt uttalelsene fra rasediskrimineringskomiteen. CESCR har uttalt at når urfolks territorier har blitt kolonisert, eller på annen måte tatt i bruk av ikke-urfolk uten samtykke, skal statene ta skritt for å returnere disse territoriene. ${ }^{20}$

På en lignende måte har FNs menneskerettighetskomité, med adresse til en statlig part (Guatemala), uttalt at «den beklager at det ikke har vært mulig å vedta lovgivning [572] som er utformet for å garantere full deltakelse i alle [urfolkssamfunns] rettigheter under konvensjonen, inkludert restitusjon av felleseid land». ${ }^{21}$

Oppsummert viser Åhren til at de tre FN-overvåkningsorganene som er mest relevante for urfolksrettighetsdiskursen, alle har konkludert med at urfolkssamfunns rettigheter til landområder omfatter en rett til restitusjon med hensyn til land som er tatt fra dem uten samtykke i nyere tid. ${ }^{22}$

18 Åhren, Indigenous Peoples' Status in the International Legal System, s. 196 med henvisning til ICERD, General Recommendation No. 23, 5.

19 Åhren, Indigenous Peoples' Status in the International Legal System, s. 196 med henvisning til CERD / C / PRY / CO / 1-3 15 og 16. Han peker (på s. 197) på at Den interamerikanske kommisjonen for menneskerettigheter (IACHR) i Yakey Axa og Sawhoyamaxa eksplisitt oppfordret den statlige part til å bidra til restitusjon av disse samfunnenes tradisjonelle landområder. I den konkluderende observasjoner uttrykte ICERD særlig bekymring for at disse samfunnenes landområder ikke hadde blitt returnert.

20 Åhren, Indigenous Peoples' Status in the International Legal System, s. 196 med henvisning til CESC General Comment No 21, 36.

${ }^{21}$ Åhren, Indigenous Peoples' Status in the International Legal System, s. 196 med henvisning til Human Rights Committee, 72th session, Consideration of reports submitted by states parties under article 40 of the covenant, Concluding observations of the Human Rights Committee Republic of Guatemala (CCPR/CO/72/GTM) avsnitt 29.

22 Åhren, Indigenous Peoples' Status in the International Legal System, s. 196. 


\subsection{FNs erklæring om urfolks rettigheter}

FNs erklæring om urfolks rettigheter ble vedtatt av et stort flertall av verdens stater i FNs generalforsamling 13. september $2007,{ }^{23}$ og er således det nyeste folkerettsdokumentet vedtatt for å verne om urfolks rett til deltakelse i beslutninger, selvbestemmelse, kultur og landrettigheter. Erklæringen er ikke en internasjonal avtale nasjonalstater kan forplikte seg til gjennom ratifikasjon. Den er likevel ikke uten rettslig betydning, nettopp på grunn av dens betydelige internasjonale oppslutning. Den kan således, som påpekt av Jens Edvin A. Skoghøy, tas som uttrykk for statspraksis, «noe som igjen kan danne folkerettslig sedvane». ${ }^{24}$ Det kan her også vises til at førstvoterende i Nesseby-dommen har uttalt at

«FNs urfolkserklæring (UNDRIP), vedtatt på FNs generalforsamling i 2007, må anses som et sentralt dokument innenfor urfolksretten, blant annet som følge av at den reflekterer folkerettslige prinsipper på området og har fått støtte fra svært mange stater» (avsnitt 97).

Førstvoterende påpeker også at nasjonalstatene i 2014 bekreftet sin støtte til erklæringen gjennom en særskilt resolusjon på generalforsamlingen, uttrykt i 69/2 Outcome document. Det må også vektlegges at erklæringen er nyttet for å utfylle internasjonale traktater, ${ }^{25} \mathrm{og}$ at Högsta domstolen i vårt naboland Sverige nytter den for å begrunne en samebys forvaltningsrett til byens tradisjonelle landområde. ${ }^{26}$ [573] Urfolkserklæringen reflekterer langt på vei standpunktene de nevnte FN-organene i punkt 2.2 ovenfor har gitt uttrykk for når det gjelder retten til restitusjon. I henhold til artikkel 28 (1) har urfolk rett til gjenoppretting, restitusjon og tilbakeføring av landområder. Om dette ikke er mulig, har vedkommende folk rett til rettferdig og riktig kompensasjon for områder de har eid eller på annen måte har befolket eller brukt, og som er konfiskert eller på annen måte fratatt dem mot deres vilje. Artikkel 28 lyder i norsk oversettelse ${ }^{27}$ slik:

${ }^{23} 144$ stater stemte for erklæringen, mens fire stater, Australia, Canada, New Zealand og USA (forkortet CANZUS), stemte imot erklæringen. Elleve stater unnlot å stemme. De fire som stemte imot, har senere reversert sitt standpunkt, se Øyvind Ravna, Same- og reindriftsrett, Gyldendal, Oslo 2019, s. 203. Se også St.meld. nr. 28 (2007-2008) Samepolitikken s. 34.

${ }^{24}$ Jens Edvin A. Skoghøy, Rett og rettsanvendelse, Universitetsforlaget 2018, s. 211.

${ }^{25}$ Tiina Sanila-Aikio vs. Finland (Communication No. 2668/2015) avsnitt 6.8 og 6.9, hvor erklæringen nyttes for å tolke FNs konvensjon om sivile og politiske rettigheter artikkel 1 og 27.

${ }^{26}$ Högsta domstolen, Staten genom Justitiekanslern mot Girjas sameby, dom 23. jan 2020 (T-853-18), avsnitt 131.

${ }^{27}$ Se FNs erklæring om urfolks rettigheter på regjeringen.no. I autentisk tekst lyder artikkel 28 slik:

1. Indigenous peoples have the right to redress, by means that can include restitution or, when this is not possible, just, fair and equitable compensation, for the lands, territories and resources which they have traditionally owned or otherwise occupied or used, and which have been confiscated, taken, occupied, used or damaged without their free, prior and informed consent. 
«1. Urfolk har rett til avhjelping, for eksempel i form av gjenoppretting eller, dersom dette ikke er mulig, en rettferdig og rimelig erstatning, for de landområder, territorier og ressurser de tradisjonelt har eid eller på annen måte har befolket eller brukt, og som er blitt konfiskert, fratatt dem, okkupert, brukt eller påført skade uten deres frie og informerte forhåndssamtykke.

2. Med mindre vedkommende folk på annet vis og på fritt grunnlag har gitt sitt samtykke, skal erstatning ytes i form av landområder, territorier og ressurser av samme kvalitet og med samme størrelse og rettslige status, eller i form av økonomisk erstatning eller annen passende godtgjøring.»

Federico Lenzerini viser at ved framforhandlingen av erklæringen uttrykte flere stater bekymring vedrørende virkningen artikkel 28 kunne få på eldre, etablerte forhold. Til tross for dette er det ifølge Lenzerini ubestridt at artikkel 28 kan nyttes som hjemmel for krav rettet mot fortidens landbeslag. Han viser til at dette tydelig fremgår av ordlyden: «have the right to redress [...] for the lands, territories and resources $[\ldots]$ which have been confiscated, taken, occupied, used or damaged» ${ }^{28}$

Dette var nasjonalstatene vel innforstått med da de ga sin tilslutning til erklæringen. For å understreke det viser Lenzerini samme sted til at New Zealand, som i 2007 unnlot å signere erklæringen, ${ }^{29}$ pekte på at artikkel 28 ser ut til å innebære at «hele landet faller innenfor rammen av artikkelen». [574]

Lenzerini påpeker videre (samme sted) at under alle omstendigheter er realiteten at artikkel 28 gjelder for tilfeller hvor urfolk er fratatt landområder i fortiden, særlig fordi effekten av mange slike beslag av landområder gjør seg gjeldende den dag i dag. Det er derfor ikke treffende å betrakte dette som «tilbakevirkende rettsanvendelse». Reelt sett, ut fra det spesielle forholdet urfolk har til sine tradisjonelle landområder, fortsetter de, selv etter mange generasjoner, i stor grad å bli negativt påvirket av tap av disse landområdene. Det innebærer, ifølge Lenzerini, at belastningene av tapt land medfører at urfolk rent faktisk har rett til oppreisning på grunn av den urett de reelt opplever i nåtiden. Han påpeker at dette er blitt bekreftet av ILOs overvåkningsorganer i Thulesaken. ${ }^{30}$

Situasjonen til Lakotafolket, eller «Sioux Nation of Indians», som fikk store landområder beslaglagt av De forente stater på 1870-tallet, og som vant fram i landets høyesterett, men uten å få sitt landområde

2. Unless otherwise freely agreed upon by the peoples concerned, compensation shall take the form of lands, territories and resources equal in quality, size and legal status or of monetary compensation or other appropriate redress.

${ }^{28}$ Lenzerini, «Reparation, Restitution, and Redress. Articles 8(2), 11(2), 20(2), and 28», s. 590.

${ }^{29}$ I 2010 var New Zealand det andre av de fire CANZUS-landene, som i 2007 stemte mot urfolkserklæringen (se note 23 ovenfor) til å endre sitt standpunkt, se Kiri Rangi Toki, «What a Difference a 'Drip’ Makes: The Implications of Officially Endorsing the United Nations Declaration on the Rights of Indigenous Peoples», Auckland University Law Review, Vol. 16, 2010 s. 243-244.

${ }^{30}$ Lenzerini, «Reparation, Restitution, and Redress. Articles 8(2), 11(2), 20(2), and 28», s. 590 med henvisning til Representation (Article 24), 2000, Denmark, se punkt 2.1 og sak referert i note 12 ovenfor. 
tilbake (i sak vist til i note 6 ovenfor), viser at Lenzerinis argumenter er høyst relevante. Dette folket ligger i dag Øverst på fattigdoms- og negative helsestatistikker i USA, noe som kan knyttes til tvangsforflyttinger til avgrensede reservater på 1870-tallet og senere helseskadelig mineralvirksomhet i området. $^{31}$

Hovedkriteriet for restitusjon etter artikkel 28 er tradisjonell bruk og besittelse, heller enn formell statlig anerkjennelse av rettigheter. Det innebærer ifølge Åhren at uttrykket «tradisjonelt har eid eller [...] befolket eller brukt» må ha den samme betydningen i artikkel 28 (1) som i artikkel 26 (2). ${ }^{32}$ Dermed bør bestemmelsen også forstås i den kulturelle sammenhengen til vedkommende urfolk.

\subsection{Status i internasjonal rett}

Ifølge FNs erklæring om urfolks rettigheter artikkel 28 (1) skal retten til et område et urfolk eller en urfolksgruppe historisk har brukt og bebodd på en måte som samsvarer med deres kultur, men som senere uten samtykke er blitt fratatt dem, som hovedregel tilbakeføres. Er ikke det mulig, har de krav på andre former for kompensasjon, helst gjennom tildeling av andre landområder som dekker deres behov. Denne regelen støttes av praksis fra ILO-organer og uttalelser i ILO-organenes retningslinjer (guidelines). [575]

Det kan her medtas at ILO-konvensjon nr. 169, som andre konvensjoner, må tolkes i lys av konvensjonens formål, ${ }^{33}$ som for ILO 169 dels kan sies å være «å verne disse folks rettigheter og [...] å garantere at deres integritet blir respektert» og som dels nettopp er å anerkjenne «[v]edkommende folks eiendoms- og råderett til de landområder som de tradisjonelt besitter», jf. hhv. artikkel 2 (1) og 14(1). Det er dermed naturlig, slik ILO-organene gjør, å innfortolke en gjenopprettende funksjon i artikkel 14 da dette bidrar til å realisere konvensjonens formål.

Mattias Åhren viser dessuten til at tre andre, sentrale FN-organer gir uttrykk for samme oppfatning som uttrykkes i urfolkserklæringen artikkel 28 (1).

Såvel Åhren som Lenzerini påpeker viktigheten av å se restitusjonsretten i en kulturell sammenheng, hvor former for gjenoppretting og erstatning skal brukes med formål å rette opp brudd på urfolks kollektive og/eller individuelle menneskerettigheter.

\section{Rettsgrunnlag i norsk rett}

\footnotetext{
${ }^{31}$ Ravna, Fra Little Bighorn til Standing Rock. En moderne indianerhistorie, s. 215-218.

32 Åhren, Indigenous Peoples' Status in the International Legal System, s. 196, sml. s. 178.

${ }^{33}$ Wien-konvensjonen om traktatretten 23. mai 1969, hvor artikkel 31 første avsnitt lyder slik: «A treaty shall be interpreted in good faith in accordance with the ordinary meaning to be given to the terms of the treaty in their context and in the light of its object and purpose.»
} 


\subsection{ILO 169 og Finnmarksloven}

ILO-konvensjon nr. 169 om urfolk og stammefolk i selvstendige stater er ratifisert av Norge, noe som betyr at landet er rettslig forpliktet av konvensjonen. ILO 169 er videre gitt en sektoriell inkorporering gjennom finnmarksloven $\S 3$, som lyder slik:

«Loven gjelder med de begrensninger som følger av ILO-konvensjon nr. 169 om urfolk og stammefolk i selvstendige stater. Loven skal anvendes i samsvar med folkerettens regler om urfolk og minoriteter og bestemmelser i overenskomster med fremmede stater om fisket i grensevassdragene.»

Dette kan tyde på at ILO 169 skal ha en bred plass i rettskartleggingen i Finnmark. Høyesterett har imidlertid, i Stjernøya-dommen, lagt til grunn at begrensningene stilt opp i $§ 3$ første punktum, ikke legger føringer på de materielle reglene for rettskartleggingen i Finnmark:

«Uttalelsen om at ILO-konvensjonen ikke skal brukes til ‘å bygge ut finnmarksloven’ [Innst. O. nr. 80 (2004-2005) s. 33] understreker at inkorporeringen var ment å begrense seg til finnmarkslovens egne bestemmelser. Selv om loven regulerer prosedyrene for å avklare rettigheter, regulerer den ikke de materielle reglene som rettighetene skal avklares på [576] grunnlag av. At rettigheter ikke kan utledes 'direkte fra ILO-konvensjonen', er dessuten uttrykkelig presisert i flertallets merknader til lovens $§ 5$ på side 36 i innstillingen» (HR-2016-2030-A avsnitt 76, min utheving).

Med andre ord har ikke ILO 169 forrang fremfor reglene som skal brukes for å avklare rettighetene på Finnmarkseiendommens grunn, men kun foran lovens egne bestemmelser.

Dette gjentas av Høyesterett i plenum i HR-2018-456-P (Nesseby) avsnitt 102.

\subsection{Høyesterett om retten til restitusjon i ILO 169}

Samtidig som Høyesterett avviser at ILO 169 har materiell betydning for rettskartleggingen i Finnmark, bekrefter den i HR-2018-456-P (Nesseby), etter anførsel fra Nesseby bygdelag, at artikkel 14 (1) første punktum er ment å ha en gjenopprettende funksjon. Det er dermed ikke avgjørende om staten eller andre over en viss periode har hatt rådighet over områder som tidligere har vært benyttet av urfolket: «Et slik utgangspunkt må generelt sett være riktig, og har støtte i forarbeidene til ILO-konvensjon nr. 169» (avsnitt 173).

Med andre ord tydeliggjør Høyesterett at retten til restitusjon, slik den er forstått av ILO-organene og FN-organene nevnt i punkt 2.2 ovenfor, er en del av norsk rett. I Nesseby-dommen fant imidlertid ikke Høyesterett grunn til å gå nærmere inn på prinsippet slik det rettshistoriske faktum i saken ble fremstilt, da «så vel andre gruppers bruk som statens disposisjoner har pågått i flere hundre år» (avsnitt 173). 


\subsection{Finnmarkskommisjonens Karasjok-utredning}

Som vist unnlot Høyesterett på grunn av de faktiske forhold som ble lagt til grunn i Nesseby-saken, å anvende restitusjonsregelen. I Karasjok-utredningen legger Finnmarkskommisjonen til grunn at verken statens eiendomsrettslige disposisjoner eller andres bruk har hatt et slikt omfang, eller har vært like langvarige, som i Nesseby.

Kommisjonens flertall finner dermed grunn til å legge betydelig vekt på ILO 169 artikkel 14 (1) første punktum når den tar stilling til lokalbefolkningens rettigheter. En årsak til dette er nettopp at kommisjonen vektlegger at artikkel 14 (1) første punktum har en gjenopprettende funksjon. Det blir her vist til Nesseby-dommen og uttalelsen om at denne funksjonen på generelt grunnlag gjelder. ${ }^{34}$ Kommisjonen legger etter det til grunn at statens disposisjoner som det i første rekke er relevant å [577] trekke inn i vurderingen (som eierrådighet), fant sted i perioden fra tidlig 1900-tall til et stykke ut på 1970-tallet. Eldre eiendomsoppmålinger og matrikuleringer blir i sin tur vurdert å være stadfesting og registrering av eksisterende etablert bruk.

Kommisjonen fortsetter med å påpeke at om den samiske bruken hadde opphørt i denne perioden, og det ikke lenger var noen forbindelse mellom den bruken som opprinnelig ble utøvd, og dagens situasjon, kunne rundt 70 år etter forholdene vært tilstrekkelig (for bortfall). Formuleringen «traditionally occupy» $\mathrm{i}$ artikkel 14 (1) første punktum innebærer imidlertid at det ikke er et krav at urfolkets rådighetsutøvelse og bruk må ha pågått med samme omfang og samme innhold som den opprinnelig gjorde, for å utløse retten til eierskap og besittelse etter artikkel $14 .{ }^{35}$ Det vises her til at Samerettsutvalgets folkerettsgruppe mente at for å oppfylle vilkåret om «traditionally occupy» ville det være tilstrekkelig «om den bruk som påberopes som grunnlag for retten», har stått ved lag til noen år inn på 1900-tallet, ${ }^{36}$ og at Justisdepartementet i forkant av Norges ratifikasjon av ILO 169 antok at det var tilstrekkelig om bruken hadde vedvart «fram til våre dager». ${ }^{37}$

Kommisjonen legger deretter til grunn at det neppe er påkrevd å gå nærmere inn på dette. På samme måte som spørsmålet om det foreligger et festnet rettsforhold eller en sedvanerettsdannelse, vil spørsmålet om eiendomsrett bero på en helhetsvurdering. Og det er da på det rene at karasjokbefolkningens bruk har vært dominerende frem til de første tiårene etter andre verdenskrig. Det legges også til grunn at befolkningen, med unntak for skog (trevirke), også i betydelig grad har styrt den lokale ressursutnyttelsen.

\footnotetext{
${ }^{34}$ Finnmarkskommisjonen, Rapport felt 4, bind 1, s. 203 med henvisning til HR-2018-456-P avsnitt 173. Den gjenopprettende funksjonen omtales også som restitusjonsprinsippet.

${ }^{35}$ Finnmarkskommisjonen, Rapport felt 4, bind 1, s. 204 med henvisning til ILO, Indigenous \& Tribal Peoples' Rights in Practice - A Guide to ILO Convention No. 169, 2009, s. 94-95.

${ }^{36}$ Finnmarkskommisjonen, Rapport felt 4, bind 1, s. 204 med henvisning NOU 1997: 5, s. 49-50.

${ }^{37}$ Finnmarkskommisjonen, Rapport felt 4, bind 1, s. 204 med henvisning til St. prp. nr. 102 (1989-90), s. 6.
} 
Videre heter det at lokale rettsoppfatninger om at retten til grunn og utmarksressurser ligger til lokalbefolkningen og ikke til staten, fortsatt står sterkt. Det betyr at

«Den usolgte grunnen i Karasjok må derfor anses omfattet av kriteriet 'traditionally occupy' i artikkel $14 \mathrm{nr} .1$ første punktum. Bestemmelsens gjenopprettende funksjon må innebære at rundt 70 års forholdsvis omfattende statlig rådighetsutøvelse fra rundt 1900 ikke vil være tilstrekkelig til at statens disposisjoner over grunn og ressurser har brutt ned den retten som forelå i $1751 .{ }^{38}[\mathbf{5 7 8}]$

Standpunktet bidrar i vesentlig grad til at Finnmarkskommisjonens flertall kom til at den usolgte grunnen i utredningsfeltet ikke er eid av Finnmarkseiendommen, men er kollektivt eid av lokalbefolkningen i Karasjok. ${ }^{39}$

\section{Oppsummering}

Tilflytting av andre folkegrupper, kolonisering og oppfatninger forankret i kulturhierarkiske og «sosialdarwinistiske» betraktninger, herunder den feilaktige lære om statens grunn i Finnmark (og andre steder), har bidratt til at samene ikke lenger har råderett over sine tradisjonelle landområder. Sammenholder man Høyesteretts forankring av retten til restitusjon i ILO 169 artikkel 14 (1) med urfolkserklæringen artikkel 28 (1) og annen internasjonal rett på området, gir dette ILO 169 relevans for spørsmålet om eiendomsretten til landområder samene ikke lenger har råderett over. En konvensjonstolkning i samsvar med Wien-konvensjonen om traktatretten støtter opp om dette.

Retten til restitusjon innebærer således at det ikke er avgjørende om staten eller andre gjennom en viss periode har hatt rådighet over områder som tidligere har vært benyttet av urfolket, når krav grunnet i «tradisjonell besittelse» eller «tradisjonelt eierskap» fremmes, jf. ILO 169 artikkel 14 (1) og urfolkserklæringen artikkel 26 (1) og (2).

Restitusjonsregelen er også forankret i samenes egen oppfatning av retten til deres tradisjonelle landområder. Allerede i 1956 uttalte Samisk råd for Finnmark at «samene lever i den sikre overbevisning at høyfjellet og nes og øyer ute ved kysten som de har hatt bruksrett til i uminnelige tider, ikke har vært herreløs eiendom, men tilhørte samene». ${ }^{40}$ I Tråante deklarationen artikkel 20 med tittel «Rätten till

\footnotetext{
${ }^{38}$ Finnmarkskommisjonen, Rapport felt 4, bind 1, s. 204 (uthevet av kommisjonen).

${ }^{39}$ Finnmarkskommisjonen, Rapport felt 4, bind 1, s. 218.

${ }^{40}$ Innstilling fra komiteen til å utrede samespørsmål (Samekomiteen) (1959) s. 34. Uttalelsen ble vedtatt som sak 8/1956 på rådsmøtet 27.-29. mars 1956. Se Ravna, Same- og reindriftsrett, s. 74.
} 
restitution», vedtatt i 2017, kommer det samiske standpunktet vedrørende restitusjon og gjenoppretting tydelig fram:

«Samiska rättigheter till land, vatten och naturresurser är inte begränsade till de områden som samer traditionellt och alltjämt brukar. De rättigheterna innefattar även territorier som samene traditionellt har brukat, men som fråntagits samerna utan samtycke. Det innefattar likaså de områden som gått förlorade genom de domstolsbeslut som tagits innan kravet på att kulturanpassa bedömningen av samiskt traditionellt bruk slagit igenom, eller bekräftats i nationell rätt [...].» ${ }^{41}$ [579]

Praksis fra Høyesterett i Nesseby-dommen viser at retten til restitusjon og gjenoppretting har en plass i norsk rett. Finnmarkskommisjonen har anvendt denne regelen på en måte som gjør at den har fått en tydeligere forankring i rettskartleggingen i Finnmark. Dette innebærer at ILO 169 har fått en fornyet aktualitet under rettskartleggingen i Finnmark, sammenliknet med utkommet av Stjernøya-dommen, og at Norge således vil kunne være bedre rustet til å ivareta sine folkerettslige forpliktelser overfor samene i Finnmark - som tiltenkt da Finnmarksloven ble vedtatt. Det er ikke usannsynlig at den praksis Finnmarkskommisjonen her har lagt til grunn, vil danne en modell for videre rettskartlegging så vel i Finnmark som i øvrige områder som tradisjonelt har vært brukt og bebodd av samer.

\footnotetext{
${ }^{41}$ Samerådet, Tråante deklarationen, Tråante 2017, https://static1.squarespace.com/static/5dfb35a66f00d54ab0729b75/t/5e748a3c85894d689a090b7f 11584695873362/Tra\%CC\%8Aante deklarationen svensk.pdf (20.06.2020).
} 